\title{
Isolation and Identification of Rhizobium species from Root Nodules of Arachis hypogaea L. and Telfairia occidentalis in South-East, Nigeria
}

\author{
Agah, M.V. ${ }^{1}$, Orji, J.O. ${ }^{2}$, Nnachi, A. U. ${ }^{3}$, Chukwu, O.S. ${ }^{4}$, Udu-Ibiam, O.E. ${ }^{5}$, Nwachi, A.C. ${ }^{6}$, \\ Olaosebikan, $0.0 .^{7}$ \\ 1, 2, 5, 6 Department of Applied Microbiology, Faculty of Science, Ebonyi State University, Abakaliki, Nigeria \\ ${ }^{3}$ Department of Medical Microbiology and Parasitology, Faculty of Medicine, Nnamdi Azikiwe University, Awka, Nigeria \\ ${ }^{4,7}$ Department of Biology/Microbiology/Biotechnology, Faculty of Science and Technology, Federal University, Ndufu Alike, Ikwo, \\ Nigeria
}

\begin{abstract}
Nutrient deficiency in the soil poses enormous challenge to food production globally. The use of synthetic nitrogen fertilizer to boost crop yield is a common farming practice, despite its untoward effects and hazard to the environment and human population. This study was aimed at isolating and identifying Rhizobium species from root nodules of Arachis hypogaea L. and Telfairia occidentalis so as to explore and maximize their contributions to soil nitrogen fertilization in place of synthetic fertilizers. A total of ten nodulated healthy plants (five each of Arachis hypogaea L. and Telfairia occidentalis plants) were collected from Ihiala and Ezzamgbo, both in south-east Nigeria and processed using standard microbiological and biochemical techniques. The result revealed ten isolates of Rhizobium species. This shows that Arachis hypogaea L. and Telfairia occidentalis plants contain nitrogen-fixing bacteria, making them capable of self-nitrogen fertilization and valuable in crop rotations.
\end{abstract}

Keywords: Rhizobium, Groundnut, Fluted Pumpkin, Isolation, Nodulation.

\section{Introduction}

The green revolution has led to intensified agriculture to meet the ever increasing demands for food and fibre [1],[2]. In 2011, the administration of President Goodluck Ebele Jonathan launched an Agricultural Transformation Agenda to promote agriculture as a business, integrate the agricultural value chain and make agriculture the key driver of Nigeria's economic growth [3]. However, the drive to intensify agriculture has constantly been challenged by poor soil fertility and to circumvent this, farmers have improved soil fertility using synthetic fertilizers.

Nitrogen is an essential plant nutrient being a component of amino acids, nucleic acids, nucleotides, chlorophyll, enzymes and hormones. However, almost all soils are deficient of nitrogen; hence nitrogen is considered a limiting element [4]. Although nitrogen occupies about $78 \%$ of the atmospheric air, it is not readily accessible to plant unless in the form of soil nitrate. Synthetic fertilizers for improving soil fertility are rarely available to most farmers especially in the rural areas of Nigeria. In addition, these fertilizers are not environmental friendly and may induce soil acidification and reduce in efficiency after many cropping years [5], leading to a high dependence of soil on nitrogen fertilizers for optimum yield [6].

Interestingly, some plants (legumes) possess a unique ability to establish symbiotic association with nitrogen-fixing bacteria of the family Rhizobiaceae. Rhizobium inoculants significantly improves yield in many leguminous crops and can minimize the use of synthetic fertilizer which is rather expensive and deteriorates soil properties [4]. Their ability to fix nitrogen in symbiosis makes them excellent colonizers of low nitrogen environment and economically friendly crop pasture [7]. In addition, nitrogen from legume fixation is essentially "free" for use by both the host plant and associated or subsequent crops [8]. A well-established practice for maintaining soil fertility has been the cultivation of leguminous plants which replenish atmospheric nitrogen through symbiosis with Rhizobium species in rotation with non-leguminous plants [9].

Groundnut and fluted pumpkin are two important indigenous food crops in Nigeria [10],[11]. Groundnut, also known as peanut (Arachis hypogaea L.) is crop of global importance. It is widely grown in the tropics and subtropics, and classified both as a grain legume and an oil crop [12]. Like most other legumes, groundnuts harbour nitrogen-fixing bacteria in their root nodules, making then require less nitrogen-containing fertilizer and valuable in crop rotations. Fluted pumpkin (Telfairia occidentalis) is a tropical vine grown in West Africa as a leafy vegetable and for its edible seeds. It is indigenous to southern Nigeria [13], where it is used primarily in soup and herbal medicine [14]. The fluted gourd is high in oil (30\%) [13], the shoot is high in potassium and iron, while the seeds are composed of $27 \%$ crude protein and $53 \%$ fat [15]. The leaves contain a high amount of antioxidants and hepatoprotective and antimicrobial properties [14].

Although this vegetable is widely eaten in southern Nigeria for its nutritional and medicinal values, adequate information is lacking about its contribution to soil fertility and nutrient cycling. Therefore, this study was carried out to isolate and identify the nitrogen-fixing bacterium (Rhizobium spp.) from 


\section{International Journal of Science and Research (IJSR)}

ISSN (Online): 2319-7064

Index Copernicus Value (2013): 6.14 $\mid$ Impact Factor (2015): 6.391

Arachis hypogaea L. and Telfairia occidentalis so as to explore their environmental friendly contributions to soil fertilization.

\section{Materials and Methods}

\subsection{Collection of Nodulated Roots of Arachis hypogaea $\mathrm{L}$. and Telfairia occidentalis}

A total of ten nodulated plants (five each of pumpkin and groundnut) were collected from organic farms at Ezzamgbo and Ihiala (both in south-east, Nigeria) respectively. Healthy pumpkin plants were uprooted carefully and those plants possessing healthy nodules with pink colour were selected and transported to the Department of Applied Microbiology Laboratory Complex of Ebonyi State University, Abakaliki in polythene bags for immediate processing.

\subsection{Isolation of Rhizobium species}

Isolation of rhizobium was done using yeast extract mannitol agar (YEMA) as described by Rajendran et al. [16]. In this, healthy, unbroken, firm and pink nodules were selected for the isolation. They were washed under tap water to remove adhering mud and soil particles, after which they were treated carefully with $5 \%$ hydrogen peroxide for surface sterilization. The nodules were repeatedly washed in sterile water for 34 mins to get rid of the sterilant and then treated with $70 \%$ ethyl alcohol for about one minute and $0.1 \% \mathrm{HgCl}_{2}$ for two minutes. They were washed with sterile water (3 successive times) under aseptic conditions and crushed with sterile crucible. A suspension was made of the crushed nodules, plated on YEMA medium containing 1\%Congo-red dye and incubated at $28 \pm 1^{\circ} \mathrm{C}$ for 24 hours. Growth on YEMA plate was observed after the said incubation period.

\subsection{Identification of Rhizobium species}

Pure cultures of the isolates were made and then subjected to Gram reaction. The Gram negative isolates were further subjected to biochemical tests including catalase, oxidase, voges-Proskauer and indole tests for confirmation. Flagellation test was carried out to test for motility using flagella mordant (Loffler's mordant).

\subsection{Seed Inoculation of Arachis hypogaea $\mathbf{L}$. and Telfairia occidentalis with Pure Culture of Rhizobium}

Slants of modified Jensen's medium were made. Single seed producing radical in down position was aseptically transferred into slants. So that radical was in direct contact with the gelled medium. Then 2-5 drops of log phase culture of rhizobium isolated from pumpkin and groundnut were added and kept as uninoculated (control). The bases of the tubes were covered with black paper so as to create darkness required for growth of root system. Test tubes were plugged with non-absorbent cotton plug. The germinated seed were exposed to sunlight periodically. Tubes were incubated for 20-30 days and effect on growth in inoculated and uninoculated tubes was observed and recorded.

\section{Results and Discussion}

In this present study, strains of root nodulating bacteria were isolated from the root nodules of Arachis hypogaea L. and Telfairia occidentalis plants growing in south-east, Nigeria. During this study ten (10) isolates of Rhizobium spp. were recovered from Arachis hypogaea L. and Telfairia occidentalis roots. The bacteria that nodulate these plants roots have been routinely considered as belonging to the miscellaneous group Bradyrhizobium spp., comprising a large number of slow-growing strains capable of nodulating several species of herbaceous legumes common in the tropical region [17],[18]. In this study, approximately all of isolates obtained from the different samples showed rapid growth in culture medium indicating that the limit strain capable of Arachis hypogaea L. and Telfairia occidentalis nodular goes beyond the group's Bradyrhiobium spp. Some studies already showed the fast-growing Rhizobia are more common in arid regions. This feature is a survival strategy, since they are more drought tolerant than slow-growing and multiply rapidly in a short period of wet weather, which would explain its greater frequency in soils of semiarid regions [19].

The colonies of rhizobia species isolated from Arachis hypogaea L. and Telfairia occidentalis plants nodules isolated in this study were mucoid, rod-shaped, raised with smooth edges and musky odour of the colony was observed under low power microscope. Five (5) samples each of root nodules from Arachis hypogaea L. and Telfairia occidentalis plants were found positive for Rhizobium spp. after screening through a series of various biochemical and sugar fermentative tests. The isolates showed hazy appearance on the motility media and also were positive for Catalase tests. The samples were found negative for Gram reaction tests (Table 1). The results showed that all the isolates showed mucus production, although some have little mucus. The mucoid production would represent a mechanism involved in the process of adaptation and survival of Rhizobium in adverse conditions of soil and climate. According to Freitas et al. [20], the lack of description of strains that produce an excess of using exopolysaccharides in literature caused some omission on this group of bacteria for quite some time, believing that contaminants. The mucus production changes the permeability of the cells, making strains more resistant to biotic factors of competition on the soil in the presence of ntibiotic producing microorganisms. Batista et al. [21] observed trend of increased mucus production by Bradyhizobium isolates, as a result of adaptation to conditions of acid soils of some areas. Similarly, Farrukh et al. [22] isolated Rhizobium leguminosarum which were associated with groundnut. All the strains showed growth in three days and turned the yeast extract mannitol agar media containing bromothymol blue to yellow colour confirming that all were fast growers and acid producers as reported by Alemayehu [23].

The biochemical tests performed on the isolates showed that most were positive for catalase, Oxidase, Voges - Proskauer and indole tests. Only one Rhizobium isolate from pumkin was negative to oxidase test. These findings are in close 


\section{International Journal of Science and Research (IJSR) \\ ISSN (Online): 2319-7064}

Index Copernicus Value (2013): 6.14 | Impact Factor (2015): 6.391

agreement with Javed and Asghari [24] who have previously characterized the Rhizobium from soil and root nodules of groundnut with same positive biochemical tests. Similarly, Oblisami [25] studied the nodulation pattern in legume plants by screening through the same tests and reported similar results. Singh et al. [26] characterized Rhizobium strain from the roots of groundnut bacterial species. These findings corroborate with the results of Singh et al. [26], and Erum and Bano [27] who also reported these sugar tests positive during isolation and characterization of Rhizobium meliloti on most of leguminous plant roots.

Table 1: Morphological and Biochemical Characteristics of Rhizobium species from Root Nodules of Arachis hypogaea L.

(Groundnut) and Telfairia occidentalis (Fluted Pumpkin) in South-East, Nigeria.

\begin{tabular}{|c|c|c|c|c|c|c|c|c|c|}
\hline Sample & $\begin{array}{c}\text { Colonial } \\
\text { characteristics }\end{array}$ & $G R$ & $S$ & Catalase & Oxidase & Motility & $V P$ & Indole & $\begin{array}{c}\text { Suspected } \\
\text { organism }\end{array}$ \\
\hline G1 & $\mathrm{Mg}$ & - & $\mathrm{Rd}$ & + & + & + & + & + & Rhizobium spp. \\
\hline $\mathrm{G} 2$ & $\mathrm{Mg}$ & - & $\mathrm{R}$ & + & + & + & + & + & Rhizobium spp. \\
\hline G3 & $\mathrm{Mg}$ & - & $\mathrm{Rd}$ & + & + & + & + & + & Rhizobium spp. \\
\hline G4 & $\mathrm{Mg}$ & - & $\mathrm{R}$ & + & + & + & + & + & Rhizobium spp. \\
\hline G5 & $\mathrm{Mg}$ & - & $\mathrm{Rd}$ & + & + & + & + & + & Rhizobium spp. \\
\hline P1 & $\mathrm{Mg}$ & - & $\mathrm{Rd}$ & + & + & + & + & + & Rhizobium spp. \\
\hline $\mathrm{P} 2$ & $\mathrm{Mg}$ & - & $\mathrm{R}$ & + & + & + & + & + & Rhizobium spp. \\
\hline P3 & $\mathrm{Mg}$ & - & $\mathrm{Rd}$ & + & - & + & + & + & Rhizobium spp. \\
\hline $\mathrm{P} 4$ & $\mathrm{Mg}$ & - & $\mathrm{R}$ & + & + & + & + & + & Rhizobium spp. \\
\hline $\mathrm{P} 5$ & $\mathrm{Mg}$ & - & $\mathrm{Rd}$ & + & + & + & + & + & Rhizobium spp. \\
\hline
\end{tabular}

Key:

$R d=$ Round shape

$R=$ Rod shape

$M g=$ Mucoid in texture (grey colour)

$G R=$ Gram Reaction

VP= Voges - Proskauer

$S=$ Shape

The biochemical tests performed on the isolates showed that most were positive for catalase, Oxidase, Voges - Proskauer and indole tests. Only one Rhizobium isolate from pumkin was negative to oxidase test. These findings are in close agreement with Javed and Asghari [24] who have previously characterized the Rhizobium from soil and root nodules of groundnut with same positive biochemical tests. Similarly, Oblisami [25] studied the nodulation pattern in legume plants by screening through the same tests and reported similar results. Singh et al. [26] characterized Rhizobium strain from the roots of groundnut bacterial species. These findings corroborate with the results of Singh et al. [26], and Erum and Bano [27] who also reported these sugar tests positive during isolation and characterization of Rhizobium meliloti on most of leguminous plant roots.

\section{Conclusion}

Rhizobium is an important microorganism for the environment because of its nitrogen-fixing ability when in symbiotic relationship with plants (mainly legumes). This study confirmed that the root nodules of fluted pumpkin and groundnut plants harbour the nitrogen-fixing bacteriumRhizobium. It also showed that these plants when inoculated with Rhizobium isolates perform better. This organism will greatly enhance agricultural production, if they are often used to inoculate legume plants, thereby reducing the environmental threat of synthetic nitrogen fertilizers.

\section{References}

[1] M. Wik, P. Pingali and S. Broca, "Background Paper for the World Development Report 2008: Global
Agricultural Performance: Past Trends and Future Prospects", Washington, DC: World Bank, 2008.

[2] P. L. Pingali, "Green Revolution: Impacts, limits, and the path ahead," Proc Natl Acad Sci U S A., vol. 109, no. 31, pp. 12302-12308, 2012.

[3] Adesina, "Agricultural Transformation Agenda: Repositioning agriculture to drive Nigeria's economy" Available at:http://www.emrc.be/documents/document/201212051 20841-agri2012-special_session-tony_bellomin_agric_nigeria.pdf

[4] N. N. Laurette, N. B. Maxémilienne, F. Henri, A. Souleymanou, K. Kamdem, N. Albert, N. Dieudonné and E. François-Xavier, "Isolation and Screening of Indigenous Bambara Groundnut (Vigna Subterranea) Nodulating Bacteria for their Tolerance to Some Environmental Stresses," American Journal of Microbiological Research, vol. 3, no. 2, pp. 65-75, 2015.

[5] B.V. Bado, "Rôle des légumineuses sur la fertilité des sols ferrugineux tropicaux des zones guinéennes et soudaniennes du Burkina Faso," PhD thesis, Université Laval, Laval, Canada, 2002.

[6] J.O. Fening and S.K.A. Danso, "Variation in symbiotic effectiveness of cowpea bradyrhizobia indigenous to Ghanaian soils," Appl. Soil Ecol., vol. 21, pp. 23-29, 2002

[7] E.S. Jensen and H. Hauggaard-Nielsen, "Understanding the role of grain legumes in the $\mathrm{N}$ cycling of agroecosystems, Grain Legumes," vol. 36, no. 2, pp. 12 14,2002

[8] E.T. Kiers, S.A. West and R.F. Denison, "Mediating mutualisms farm management practices and evolutionary changes in symbiont co-operation," J. Appl. Ecol., vol. 39, pp. 745-754, 2002. 


\section{International Journal of Science and Research (IJSR) \\ ISSN (Online): 2319-7064}

Index Copernicus Value (2013): 6.14 | Impact Factor (2015): 6.391

[9] A.K. Deka and P. Azad "isolation of Rhizobial strains cultural and Biocemical Characteristics," Legume. Res., vol. 29, pp. 3, pp. 209-212, 2006.

[10]A.A.A. Kayode and O.T. Kayode, "Some medicinal values of Telfairia occidentalis: A review," Am. J. Biochem. Mol. Biol., vol. 1, pp. 30-38, 2011.

[11] O.M. Bamshaiye, J.A. Adegbol and E.I. Bamishaiye, "Bambara groundnut: an Under-Utilized Nut in Africa," Advances in Agricultural Biotechnology, vol. 1, pp. 6072, 2011.

[12] Wikipedia, "Peanut," Available at: https://en.wikipedia.org/wiki/Peanut.

[13] M.O. Akoroda, "Ethnobotany of Telfairia occidentalis (c uc-urbitaceae) among Igbos of Nigeria," Econ. Bot., vol. 44, pp. 29-39, 1990.

[14]E.E. Nwanna, "Antioxidant and hepatoprotective properties of Telfaria occidentalis leaf (fluted Pumpkin)" Thesis and Dissertations (Biochemistry), 56 pp. 2008.

[15]I.O.O. Aiyelaagbe, and A.A Kintomo. "Nitrogen Response of Fluted Pumpkin (Telfairia occidentalis Hook. F) Grown Sole or Intercropped with Banana." Nutrient Cycling in Agroecosystems, vol. 64, pp. 231-35, 2002.

[16] G. Rajendran, F. Singh, A. J. Desai, and G. Archana, "Enhanced growth and nodulation of pigeon pea by coinoculation of Bacillus strains along with Rhizobium sp.," Bioresource Technology, vol. 99, pp. 4544-4550, 2008.

[17] L.M. Saleena, P. Loganathan, S. Rangarajan, S. Nair, "Genetic diversity and relationship between Bradyrhizobium strains isolated from blackgram and cowpea" Biology and Fertility of Soil, vol. 34, no. 4, pp. 276-281, 2001.

[18] J. E. Zilli, R.R. Valicheski, N.G. Rumjanek, J.L. SimõesAraújo, F.R. Freire-Filho and M.C.P. Neves, "Eficiência simbiótica de estirpes de Bradyrhizobium isolados de solo do Cerrado em caupi," Pesquisa Agropecuária Brasileira, vol. 41, no. 5, pp. 811-818, 2006.

[19] C.E.R.S. Santos, N.P. Stamford, M.C. Neves, N.G. Rumjanek, R.V. Borges and A.D.S. Freitas, "Diversidade de rizóbios capazes de nodular leguminosas tropicais," Revista Brasileira de Ciências Agrárias, vol. 2, no. 4, pp. 249-256, 2007.

[20] A.D.S. Freitas, C.L. Vieira, C.E.R.S. Santos, N.P. Stamford and M.C.C.P. Lyra, "Caracterização de rizóbios isolados de jacatupé cultivado em solo salino do Estado de Pernambuco", Brasil. Bragantia, vol. 66, no. 3, pp. 497-504, 2007.

[21] J.S.S. Batista, M. Hungria, F.G. Barcellos, M.C. Ferreira and I.C. Mendes, "Variability in Bradyrhizobium japonicum and B. elkanii seven years after introduction of both the exotic microsymbiont and the soybean host in a cerrados soil" Microbial Ecology, vol. 53, no. 2, pp. 270-284, 2007.

[22] I.N. Farrukh, M. Muhammad-Ashraf, K.A. Malik and Y.H. Fauzia, "Competitiveness of introduced Rhizobium strains for nodulation in fodder legumes," Pak, J. Bot., vol. 36, no. 1, 159-166, 2004.

[23] W. Alemayehu, "The effect of indigenous Root Nodulating Bacteria on Nodulation and Growth of faba bean (Vicia faba) in low input agricultural systems of Tigray Highlands, Northern Ethopia," MEJS (Mekelle University), vol. 1, no. 2, pp. 30-43, 2009.

[24] K. Javed and B. Asghari, "Potential allelopathic effects of sunflowers on microorganisms," Afri. J.biotech., vol. 7, no. 22, 4208-4211, 2008.

[25] G. Oblisami, "an in vitro growth of five species of ectomycorrhizal fungi," Euro J for Path, vol. 1-7, pp. 204-210, 1995.

[26] Singh, R. Kaur and K. Singh, "Characterization of Rhizobium strain isolated from Trigonella foenumgraecum (Fenugreek)," Africa. J. Biotech., vol. 7, no. 20, pp. 3671-3676, 2008.

[27] S. Erum and A. Bano, "Variation in phytohormone production in Rhizobium strains at different altitudes of Northern areas of Pakistan" Int. J. Agric. Biol., vol. 10, pp. 536-540, 2008. 